Egyptian Poultry Science Journal

http://www.epsaegypt.com

ISSN: 1110-5623 (Print) - 2090-0570 (On line)

\title{
EFFECT OF SUPPLEMENTING DIET WITH SODIUM BENTONITE AND/OR ORGANIC CHROMIUM ON PRODUCTIVE, PHYSIOLOGICAL PERFORMANCE AND IMMUNE RESPONSE IN MATROUH CHICKENS STRAIN.
}

\section{2- DURING LAYING PERIOD.}

\author{
W. Ezzat ${ }^{1}$; A. E. El-Slamony'; A. M. Rizk ${ }^{1}$, I. A. Fathey ${ }^{2}$ and M.M. Sabry ${ }^{2}$ \\ ${ }^{1}$ Dept. of Poult. Breed. Res. ${ }^{2}$ Dept. of Poult. Nutr. Res. \\ Anim. Prod. Res. Insti., Agric. Res. Center, Dokki, Giza, Egypt.
}

\begin{tabular}{cc}
\hline Received:24/04/2016 Accepted: 20/05/2016 \\
\hline ABSTRACT:
\end{tabular}

ABSTRACT: The main objective of this study was to investigate the effect of sodium bentonite (Na-B) $(0,5$ and $10 \mathrm{~g} / \mathrm{kg}$ diet) and chromium picolinate $(\mathrm{CrPic})(0,800$ and 1200 $\mu \mathrm{g} / \mathrm{Cr} / \mathrm{kg}$ diet) in the diet on chicken productive and reproductive traits, some blood serum constitute, egg quality as well as the immune response. in this experiment 270 laying hens and 54 cocks of Matrouh local strain at 28 weeks of age were randomly distributed into 9 treatment groups ( 30 hens +6 cocks / each treatment) in a factorial arrangement $(3 \times 3)$. Chicken fed diets were contaminated with Aflatoxin $\left(\mathrm{AFB}_{1}\right), 7.55 \mu \mathrm{g} / \mathrm{kg}$ dry matter (DM) during the laying period.

Rations with Na-B significantly $(\mathrm{P} \leq 0.05$ or $\mathrm{P} \leq 0.01)$ improved body weight changes (BWC), egg weight, egg production and egg mass during the period from 28-40 wks of age. As well as, Haugh units, serum calcium and glutathione peroxidase (GPX) at $40 \mathrm{Wks}$ of age. Likewise, results of cocks revealed improvement blood testosterone value, percentages of sperm motility and sperm cell concentration, fertility eggs $\%$ and hatchability/total eggs. Na-B supplementation significantly $(\mathrm{P} \leq 0.05$ or $\mathrm{P} \leq 0.01)$ decreased feed intake, serum cholesterol, malonidialdehyde (MDA) values, dead spermatozoa (\%) and seminal MDA.

CrPic supplementation diet significantly $(\mathrm{P} \leq 0.05$ or $\mathrm{P} \leq 0.01)$ increased $\mathrm{BWC}$, egg weight, production rate, egg mass, yolk index, Haugh unit, thickness of egg shell, albumen percentage, the titer of sheep red blood cells (SRBCs), serum total protein, albumin, insulin and $\mathrm{Ca}$ concentrations. CrPic improved blood testosterone, physical semen properties and seminal MDA. However, significant decreased yolk weight percentage and serum cholesterol.

Moreover, egg weight and egg mass, yolk index and Haugh unit, SRBCs concentrations, and blood testosterone of cocks, sperm motility, dead spermatozoa and sperm cell concentration, values of fertility eggs $\%$ and hatchability/fertile eggs (\%) were significantly influenced by the interaction between dietary Na-B and $\mathrm{CrPic}$.

It is clear that, supplementing the chicken diet with both $10 \mathrm{~g} \mathrm{Na}-\mathrm{B}$ and $1200 \mu \mathrm{g}$ $\mathrm{CrPic} / \mathrm{kg}$ diet alone or together is recommended for improving most of productive traits, including egg and semen quality, fertility and hatchability and serum biochemical traits as well as improved immune responses.

Keywords:Sodium Bentonite- Chromium Picolinate- Productive Traits- Blood Parameters,. 


\section{INTRODUCTION}

Bentonite is a clay mineral has been used as a feed added substance effectively in poultry nourishes with no destructive impacts (Safaeikatouli et al., 2010). The swelling of bentonite causing a reduction in the rate of feed transit through the digestive tract, permitting time for more effective utilization (Damiri et al., 2010). Bentonites are white, lightweight rock stores made for the most part out of salts of hydrated aluminosilicates of sodium $(\mathrm{Na})$, potassium (K), calcium, and occasionally iron, magnesium $(\mathrm{Mg})$, zinc, nickel, etc. This bentonite have a high negative charge and are adjusted by cations, for example, $\mathrm{Mg}$, $\mathrm{K}$, and $\mathrm{Na}$ situated in the pits; hence, they don't respond with nourishment/bolster fixings and go about as latent material because of their impartial $\mathrm{pH}$ or marginally antacid nature (Khan et al., 2004). Addition of sodium bentonite was fundamentally successful in improving the negative impact of aflatoxins on the rate of phagocytosis (Moghadam et al., 2008). Sodium bentonite (Na-B) is an aluminum silicate powder that can absorb different compounds into its three layer structure (Trckova et al., 2004). This effective additive has a variety of applications in poultry industry. It has been reported that $\mathrm{Na}-\mathrm{B}$ in the diet may ameliorate aflatoxicosis (Miazzo et al., 2005). ElAbd. (2014) indicated that, chick's sustained $4 \%$ and $6 \%$ bentonite had higher body weight gain; cholesterol, lower feed intake; and better feed conversion ratio at 42 days of age contrasted with the control diet of Japanese quail chicks. Gilani et al (2013) working on commercial Hy-Line W-36 hens from 51-63 weeks of age found hen-day egg production and daily egg mass were improved $(\mathrm{P}<0.05)$ in hens fed diet containing $10 \mathrm{~g} / \mathrm{kg}$ sodium bentonite. As percentage of sodium bentonite (Na-B) increased the relative weight of liver decreased $(\mathrm{P}<0.05)$. This may was because of restricting dangerous specialist, for example, aflatoxins by Na-B. Comparative, Hashemipour et al., (2010) on laying hens and Fatouh et al., (2012) on ducks come to the same conclusion.

Chromium $(\mathrm{Cr})$ is an essential micro element that assumes a critical part in nutrition of Animal and human being and it help improving the haugh unit, albumin quality and yolk index also, $\mathrm{Cr}$ is also called as "Glucose Tolerance Factor" because it helps in potentiation of insulin metabolism. Supplementation of $\mathrm{Cr}$ and ascorbic acid can improve the nitrogen, calcium, iron, zinc and phosphorus consumption (Nattapon et al., 2012). Also, previous studies reported that $\mathrm{Cr}$ supplementation resulted in higher egg production, egg weight, mass and albumin quality (Kim et al., 1997; Uyanık et al., 2002 and Y1ldiz et al., 2004). Sahin et al., (2001b) reported that natural $\mathrm{Cr}$ supplementation, especially at $1200 \mathrm{ppb}$, expanded the execution criteria, egg quality and serum insulin concentration of Japanese quails. Then again, $\mathrm{Cr}$ supplementation underpins the immune function by upgrade the cell intervened and humoral immune responses (Lien et al., 2005). The $\mathrm{Cr}$ in feed decays the deformities of sperm and enhance the sperm number, movement and thickness enhances improves the weight of egg without affecting the quality of the egg (Abd El-Samee et al., 2012). Okada et al., (1983) demonstrated an association of chromium with DNA layouts that brought about a noteworthy incitement of RNA blend in vitro. The oligopeptide lowmolecular-weight, Cr-binding protein (chromodulin) tightly binds four chromic ions before the oligopeptide obtains a conformation required for binding to the tyrosine kinase active site of the insulin receptor (Vincent, 2000). The primary role of $\mathrm{Cr}$ in metabolism is to potentiate the action of insulin through its presence in an organometallic molecule (the glucose tolerance factor) (Anderson, 1994). Chromium is an insulin potentiator, 
therefore, postulated to function as an antioxidant (Preuss et al., 1997).

Therefore, the objective of this study was to assess the impact of supplementing different levels of Na-B and $\mathrm{CrPic}$ in the diet on chicken performance productive traits, egg quality, semen quality, fertility and hatchability, serum biochemical characteristics and in addition the safe reaction amid laying period.

\section{MATERIALS AND METHODS}

The trial work of this study was carried out at Inshas Poultry Research Station, Anim. Production Research Institute, Agriculture Research Center, Giza, Egypt, The experiment started from December 2015 until February 2016.

A $3 \times 3$ factorial arrangement experiment was performed including three levels of $\mathrm{Na}-\mathrm{B}(0,5$ or $10 \mathrm{~g} / \mathrm{kg}$ diet $)$ and three levels of $\mathrm{CrPic}$ contain $12.27 \% \mathrm{Cr}(0$. 800 , or $1200 \mu \mathrm{g} / \mathrm{Cr} / \mathrm{kg}$ diet). 270 laying hens and 54 cocks of Matrouh local strain at 28 weeks of age were randomly distributed into 9 treatment groups (30 hens +6 cocks / each treatment). All the treatment groups had nearly similar average body weight. Each group was divided into three replicates (10 hens and 2 cock each). The composition and chemical analysis of the experimental diet is presented in Table 1. Chickens fed diet were contaminated with Aflatoxin $\left(\mathrm{AFB}_{1}\right), 7.55 \mu \mathrm{g} / \mathrm{kg} \mathrm{DM}$ during the laying period. The ingredients of bentonite are $\mathrm{SiO}_{2}, 54.15 \% ; \mathrm{AL}_{2} \mathrm{O}_{3}$, $17.78 \% ; \mathrm{Fe}_{2} \mathrm{O}_{3}, 4.31 \% ; \mathrm{MgO}, 2.82 \%$; $\mathrm{Na}_{2} \mathrm{O}, 2.12 \% ; \mathrm{CaO}, 2.87 \% ; \mathrm{MnO}, 0.02 \%$; $\mathrm{K}_{2} \mathrm{O}, 0.62 \% ; \mathrm{TiO}_{2}, 0.16 \% ; \mathrm{P}_{2} \mathrm{O}_{5}, 0.06 \%$; $\mathrm{Cr}_{2} \mathrm{O}_{3}, 0.003 \%$; TOT/S, 0.09\%; LOl, $14.9 \%$ (Abdel-Motelib et al. 2011). The mean value of the daily ambient temperature and relative humidity during that period in the house were $15.92 \pm 0.44{ }^{\circ} \mathrm{C}$ and $58.42 \pm$ $1.98 \%$, respectively. The trial time frame stretched out for 12 weeks, from $28-40$ weeks of age. All chickens were housed exclusively in one cage. The cage was given an individual feeder and one programmed pipette consumers. Chickens were fed ad-libitum and the fresh water was accessible all the time along the exploratory period. The photoperiod along the exploratory period was altered at $16 \mathrm{~h}$. Individual body weight of laying hens was recorded at 28, 32, 36 and 40 weeks of age, while egg number and egg weight were recorded day by day and feed intake was calculated weekly. Egg mass was calculated by duplicating egg number by normal egg weight. Feed conversion ( $\mathrm{g}$ feed/g egg) was also calculated. At 40 weeks of age, around 54 eggs from each treatment were collected and incubated. After hatching, chicks were counted and non-hatched eggs were broken to determine the percentages of fertility and hatchability. Fertility was calculated as the percentage of fertile eggs from the total number of set eggs, while the hatchability was expressed as chicks hatched from fertile eggs and from total eggs.

At the end of experimental period total of six eggs (two from each replicate) from each treatment were taken to study the egg quality traits. Egg shape index \%, yolk index $\%$, shell thickness (mm), Haugh unit and percentage of egg components (yolk. albumin and shell) were determined. Haugh unit score for each egg was calculated according to Haugh (1937). Antibody response against SRBC was measured from 6 hens in each treatment at 36 wks of age. Hens were injected with $0.2 \mathrm{~mL}$ of $9 \%$ $\mathrm{SRBC}$ in $0.9 \%$ saline. Serum tests were collected on the $7^{\text {th }}$ day of every infusion to decide hostile to SRBC primary antibody titers, separately. Immune response creation was measured by an agglutination test utilizing the microtiter strategy (Trout et al., 1996). By the end of the test period, 3 hens were randomly chosen from each treatment and blood tests were acquired from the brachial vein for serum total protein, albumin, insulin, cholesterol, calcium, T3, MDA and GPX determination. Blood serum was separated by centrifugation of blood at $3000 \mathrm{rpm}$ for 
15 min and was then stored at $-20^{\circ} \mathrm{C}$ for analysis. Serum total protein, albumin, cholesterol and calcium concentrations were measured by spectrophotometer using available commercial Kits produced by Bio-diagnostic, Egypt. Insulin was determined in serum by using radioimmunoassay Kits. Serum was separated to measure triodothyronine (T3) hormone level, Radioimmunoassay (RIA) kits (diagnostic products corporation, Los Angeles, USA) were used for the assays. Malonidialdehyde (MDA) and glutathione peroxidase (GPX) concentration in serum determined by the method of Valenzuela (1991) and Weydert and Cullen (2010), respectively.

Semen was collected from cocks and artificially inseminated to hens (cock/5 hens) two times per week. Semen tests were exclusively gathered toward the end of test period by the massage method from all cocks. Semen volume was measured in graduated tubes and hydrogen-ion concentration $(\mathrm{pH})$ was measured by Universal Indicator Paper and Standard Commercial Stain. Sperm-cell concentration was determined using the spectrophotometer density meter technique with diluted semen samples (1:250) as described by Lake and Stewart (1978). Eosin-Nigrosine stain was used to determine the percent of morphologically sperm abnormalities and dead spermatozoa (Lake and Stewart, 1978). A little bead of semen from each cock was set on a warm slide, secured with a spread slide and inspected for sperm motility infinitesimally at 100x amplification. Melrose and Laing, (1970) observed the edge of the semen to ascertain an approximation of the percentage of live spermatozoa.

Data obtained were statistically analyzed using the General linear model of SAS (2004). A factorial arrangement $3 \times 3$ was used, considering the sodium bentonite and chromium picolinate supplementation level as the main effects, as follows: $\mathrm{Y}_{\mathrm{ijk}}=\mu+\mathrm{T}_{\mathrm{i}}+\mathrm{R}_{\mathrm{j}}+(\mathrm{TR})_{\mathrm{ij}}+\mathrm{e}_{\mathrm{ijk}}$ where :
$\mathrm{Y}_{\mathrm{ijk}}=$ An observation;

$\mu=$ Overall mean;

$\mathrm{T}=$ Effect of sodium bentonite supplementation level; $i=(1,2$ and 3$)$;

$\mathrm{R}=$ Effect of chromium picolinate supplementation level; $\mathrm{j}=(1,2$ and 3$)$;

$\mathrm{TR}=$ Interaction effect due to sodium bentonite and chromium picolinate levels; $\mathrm{ij}=(1,2,3 \ldots . .9)$;

eijk $=$ Random error .

Differences between treatments means were compared using Duncan's multiple range test (Duncan, 1955).

\section{RESULTS AND DISCUSSION}

\section{Body weight changes, feed intake and feed conversion:}

Results of BWC, FI and FCR as affected by $\mathrm{NaB}$ and $\mathrm{CrPic}$ and their interactions are summarized in Table 2.

Feeding $\mathrm{Na}-\mathrm{B}$ to hens had a significant increase $(\mathrm{P} \leq 0.05$ or $\mathrm{P} \leq 0.01)$ on BWC from 28-32 and 28-40 Wks. These may be a direct result of $\mathrm{Na}-\mathrm{B}$ having the capacity to enhance development execution and supplement absorbability (Miazzo et al. 2005 and Salari et al. 2006). Supplemented diets with 5 and $10 \mathrm{~g} \mathrm{NaB} / \mathrm{kg}$ diet resulted in a significant $(\mathrm{P} \leq 0.05)$ increase in FI than the control group. Similar results were reported by Pasha et al. (2008), who used different bentonite levels $(0.5 \%$ and $1.0 \%)$ in broiler diets and reported more FI in chicks fed higher levels of $\mathrm{Na}-\mathrm{B}$ (1\% NaB) than control. However, Tauqir and Nawaz, (2001) found that diminishing in FI of broiler chicks with including 2, 3 and $4 \% \mathrm{Na}-\mathrm{B}$ to diets. These might be because of increased maintenance time of digesta in lumen and more usage of supplements (Damiri et al. 2012). Hen fed diets supplemented with 5 and $10 \mathrm{~g} / \mathrm{kg}$ diet with $\mathrm{NaB}$ had the best FCR $(\mathrm{P} \leq 0.05$ or $\mathrm{P} \leq 0.01)$ when contrasted with those fed control diet during all periods. These results might be because of the improvement of egg mass and nutrient digestibility enhancement. It is worthy to note that, Na-B can play as an additive proposed to be authorized as a 
substance for the reduction of the contamination of feed by mycotoxins. Also, to the main adsorptive mechanism of aflatoxins by these binders involves the formation of double hydrogen bonds between aflatoxin $\mathrm{B} 1$ and aluminosilicate which probably decreased the losses of feed ( Desheng et al., 2005). The results of present study are supported by the findings of Nasir et al. (2000) who reported that laying hens fed diet supplemented with 1.0 or $1.5 \%$ Na-B had a significant improvement in FCR. Also, Inal et al. (2000) reported that FCR was slightly better with the highest inclusion rate of bentonite $(1.5-3.0 \%)$.

CrPic supplementation levels had a significant effect on BWC during the periods from 32-36 and 36-40 Wks of age, and FI and FCR among all period for birds. Similar results were reported by Eseceli et al. (2010) reported that chromium yeast supplementation did not affect BWC in laying hens from 40- $47 \mathrm{Wks}$ of age. Also, Hanafy (2011) indicated that $\mathrm{Cr}$ had no significant effect on overall mean of BWC and feed consumption for hens and cocks. Also, Yildiz et al. (2004) reported that supplementation of $\mathrm{Cr}$ from $\mathrm{CrPic}$ did not affect BWC and FI in laying Japanese quail. Our results uncovered that $\mathrm{BWC}$ of hens fed $\mathrm{CrPic}$ significantly $(\mathrm{P} \leq 0.01)$ higher from 28-32 and 28-40 Wks than those fed control diet. These outcomes are in understanding with Sahin et al. (2002a) who reported that increasing supplemental chromium at $200,400,800$ or $1200 \mu \mathrm{g} \mathrm{Cr} / \mathrm{kg}$ diet increased live weight of laying Japanese. Ezzat et al. (2006) found that $\mathrm{Cr}$ supplementation up to $400 \mu \mathrm{g} / \mathrm{kg}$ diet tended to improve body weight of Japanese quails. The observed increased in body weight by supplementing $\mathrm{Cr}$ is because of protein digestion system (Anderson, 1999). Also, $\mathrm{Cr}$ assumes a critical part as essential segment of the glucose resilience components (GTF), which potentiate the activity of insulin and manage fat digestion system. At low insulin level glucose is changed over into fat and put away in fat cells (Mertz, 1993). The ability of insulin to regulate glucose levels in blood and lipid metabolism is dependent upon the binding of this pancreatic hormone to specific receptors found in many peripheral tissues like adipocytes, muscle and liver, increasing the number of actual insulin receptors present in target cell. Chromium likewise has been shown to expand the real official of insulin to its receptors. The cooperation between $\mathrm{Na}-\mathrm{B}$ and $\mathrm{Cr}$ was not huge for body weight (except from 28-32 and 28-40 Wks of age) and feed consumption and conversion for hens.

\section{Egg production traits:}

Feeding Na-B levels to hen had significantly $(\mathrm{P} \leq 0.05$ or $\mathrm{P} \leq 0.01)$ increased on egg weight, egg mass, as well as egg production (except 28-32 and 32-36 Wks of age) than those fed control diet among all period for birds (Table 3). These results might be because of $\mathrm{Na}-\mathrm{B}$ content from clay minerals which can enhance supplement absorbability (Pasha et al. 2008). Generally, improvement of egg production of birds has been recommended to be due to better energy and protein utilization brought about by $\mathrm{Na}-\mathrm{B}$ which delayed feed section time, subsequently permitting more opportunity for assimilation of processed supplements in the intestinal tract of the birds. Moreover, the binding action of bentonite enables it to tie up the heavy metals and mycotoxins thus prevent its absorption by animals (Monks, 1992). The results of the present study are substantiated by the findings of Tauqir et al. (2000) and Nasir et al. (2000) who reported that laying hens fed diet supplemented with 1.0 or $1.5 \% \mathrm{Na}-\mathrm{B}$ had significantly improved egg production by 10.21 - $17.72 \%$ as compared to the control.

The data revealed that hens fed CrPic significantly $(\mathrm{P} \leq 0.05$ or $\mathrm{P} \leq 0.01)$ higher egg weight (except 28-32 and 32-36 Wks of age), production $\%$ and egg mass than control group throughout all the 
experimental periods (Table 3 ). The results of increasing egg weight, production $\%$ and egg mass with $\mathrm{CrPic}$ supplementation are consistent with earlier reports, Kim et al. (1997) revealed that feeding $800 \mathrm{ppb} \mathrm{Cr}$ from $\mathrm{CrPic}$ to laying hen diets resulted in higher egg production; egg weight and egg mass contrasted and the negative control group. Also, Sahin et al. (2001a) reported that supplementation of $400 \mathrm{ppb}$ chromium to the diet of laying hens reared under a low ambient temperature increased egg production. Sahin et al. (2002b) stated that higher doses of supplemental $\mathrm{Cr}$ increased egg production and improved egg weight in laying hens kept under low temperature. In addition, adding of $400 \mathrm{ppb} \mathrm{Cr}$ to diet of laying hens increased egg production (Piva et al., 2003). Abdel-Mageed et al. (2012) observed that feeding Japanese quail diets supplemented with $\mathrm{CrPic}$ enhanced egg production; egg weight and egg mass ratio under hot climate. . It is realized that $\mathrm{Cr}$ is included in protein combination and there is an association of $\mathrm{Cr}$ with DNA layouts that brought about a critical incitement of RNA blend. The oligopeptide low-atomic weight Cr-restricting protein (chromoduline) firmly ties four chromic particles before the oligopeptide gets an adaptation required for official to the tyrosine kinase dynamic site of the insulin receptor. In this manner, chromodulin seems to assume a part in an auto enhancement system in insulin flagging (Sahin et al. 2002a).

Results in Table 3 showed that egg weight and egg mass (except 36-40 Wks of age), were significantly ( $\mathrm{P} \leq 0.05$ or $\mathrm{P} \leq 0.01)$ influenced by the interaction between dietary Na-B and $\mathrm{CrPic}$ during all experimental period. However, egg production $\%$ was not significantly affected by these interactions.

Egg Quality: Egg quality and egg components were not significantly affected by Na-B levels in laying diets, except for Haugh units which were significantly $(\mathrm{P} \leq 0.05)$ higher than those fed control diet
(Table 4). These outcomes are in understanding with those reported by Hashemipour et al. (2010) who reported that egg quality parameters did not affected by adding Na-B to the diet. Also, Fatouh et al. (2012) found that relative weights of yolk and albumin as well as yolk index of lying were not significantly affected due to Na-B supplementation levels in Domyati and Kampell ducks diets. Then again, included $\mathrm{CrPic}$ did not influence egg shape index and egg shell rate. There was a significant $\quad(\mathrm{P} \leq 0.05$ or $\mathrm{P} \leq 0.01) \quad$ linear increased in yolk index, Haugh unit, egg shell thickness and albumen percentage and a reduction in yolk weight rate because of CrPic supplementation (Table 4). The change in some egg quality and egg components (\%) might be because of the conceivable instruments by which $\mathrm{Cr}$ could work to keep up egg quality are: (1) as an auxiliary part of egg whites or in the cross connecting of proteins, (2) $\mathrm{Cr}$ is important for the blend of ovomucin which is in charge of gel structure of egg whites, and (3) encourage exchange of activities (potentially magnesium) into the egg whites of eggs amid the plumping procedure in the uterus (Hossain, 1998). The data obtained in this study are in partially agreement with the results of Sahin et al. (2002a) who found that supplemental chromium linearly increased egg weight $(\mathrm{P} \leq 0.01)$, egg shell thickness; egg specific gravity $(\mathrm{P} \leq 0.05)$ and Haugh unit $(\mathrm{P} \leq 0.01)$ of laying Japanese. In Lohman White laying hens chromium yeast supplementation increased albumen and yolk index (Eseceli et al., 2010). Increasing egg shell thickness may due to that $\mathrm{Cr}$ stimulates and regulates the action of insulin (Anderson, 1994); thus increasing the effectiveness of insulin, $\mathrm{Cr}$ also indirectly empowers the ascorbic acid transportation (Seaborn et al., 1994) which has an important role in egg shell formation (Dorr and Balloun, 1976).

Results in Table 4 showed that yolk index and Haugh unit were significantly 
$(\mathrm{P} \leq 0.05$ or $\mathrm{P} \leq 0.01) \quad$ influenced by interaction between dietary Na-B and CrPic at the end of experimental period. However, egg shape index, egg shell thickness and egg components was not significantly affected by these interactions. Antibody response and blood constituents of Matrouh layers and blood testosterone of cocks:

SRBCs were used as antigen to quantify the antibody response. It was clear that feeding diet containing Na-B at level 5 and $10 \mathrm{~g} / \mathrm{kg}$ diet had no significant difference among treatments in total antibody response against SRBCs, serum total protein, albumin, insulin and $\mathrm{T} 3$ hormone values (Table 5). There was a significant $(\mathrm{P} \leq 0.05)$ linear increase in the serum calcium, GPX and blood testosterone of cocks and decrease in cholesterol and MDA values. These results were in agreement with those obtained by Gilani et al. (2013) who indicated that the significant difference of Na-B was not observed for total antibody response against SRBCs inoculation and not affect blood constituents (blood cells and activity of serum enzymes) of broiler. However, IgG was significantly increased with $2 \%$ Na-B at $14 \mathrm{~d}$ (2.79 vs. 3.66) after injection of SRBCs. Khanedar et al. (2012) found that addition of bentonite (1 or $1.5 \%$ from $\mathrm{Na}-\mathrm{B}$ or $\mathrm{Ca}-\mathrm{B})$ to the diet had no significant effect on the blood biochemical parameters (protein, albumin and calcium). El-Abd (2014) indicated that, there is no significant difference among treatments $(0$, $4 \%$ and $6 \%$ bentonite) in total protein, globulin, creatinine, cholesterol, LDL, HDL and triglyceride of Japanese quail chicks. Then again, Eraslan et al. (2005) discovered significant increased in plasma testosterone level in groups fed sodium bentonite, contrasted with the control group in broiler chicken at 45 days of age, and increased in testosterone level was identified in the study. This increased, was observed in all trial groups. This increased, although not definite, may be originated from the possible increase of protein kinase activity caused by aflatoxin (AF). These changes were observed in the birds which received sodium bentonite only. The explanation behind that couldn't be cleared up. The expansion was even considerably more unmistakable in the gathering $(0.5 \%$ of sodium bentonite with $1 \mathrm{ppm}$ of $\mathrm{AF}$ ) which got blend of both mixes. Additionally, observed that AF diminished testosterone level by harming testicular cells (Ortatatli et al. 2002).

Results in Table (5) pointed out that the adding of CrPic did not affect serum T3 hormone, MDA and GPX values. But it had a significant $(\mathrm{P} \leq 0.05$ or $\mathrm{P} \leq 0.01)$ linear increase in the titer of SRBCs, serum total protein, albumin, insulin and $\mathrm{Ca}$ concentrations layers and blood testosterone of cocks. While, serum cholesterol concentration significantly $(\mathrm{P} \leq 0.05)$ decreased. These results were in agreement with those obtained by Abdallah et al. (2013) reported that antibody response against SRBC (IgG) of Golden Montazah laying hens was significantly ( $P$ $\leq 0.05$ ) higher in 48 week old laying hens fed $800 \mathrm{ppb} \mathrm{Cr}$ contrasted and control or 200,400 and $600 \mathrm{ppb}$ treatment groups . ElHommosany (2008) demonstrated that total antibody and IgG titers against SRBCs were significantly higher in quail chicks received $\mathrm{Cr}$ contrasted and those of control at secondary immune responses. Also, it has been accounted for that $\mathrm{Cr}$ is of critical significance in adjusting the immune response by immunostimulatory or immunosuppressive processes as appeared by its consequences for $\mathrm{T}$ and $\mathrm{B}$ lymphocytes, macrophages, cytokine creation and the invulnerable reaction that may prompt extreme touchiness responses

( Shrivastava et al. 2002). Cytokines are small proteins or glycoproteins messenger molecules transporting information among cells. Cytokinase, together with their receptors are playing a role as control regulators of immune system by affecting the activity of other cells (Davison, 2003). 
The enhancement of immune response via $\mathrm{Cr}$ supplementation might be because of their antioxidant property. It reasons to protect immature lymphocytes from damage by free radical due to oxidation. Sahin et al. (2002b) observed that total protein and albumin fixations expanded straightly with expanding level of $\mathrm{Cr}$ supplementation of laying hens. The abnormal state of serum total proteins might be because of high protein synthesis and highly growth rate in the cells or tissues for the organic $\mathrm{Cr}$ treated (Cr Pico.) groups compared to control group, where the protein anabolism surpassed the protein catabolism. Uyanik et al. (2002) credited the positive effects of $\mathrm{Cr}$ on plasma protein its divisions to the anabolic activity of insulin interceded through expanding the amino acids union by liver, improvement the joining of a few amino acids into protein. However, Mc Namara and Valdez (2005) suggested that effect of $\mathrm{Cr}$ on lipid metabolism might be because of that $\mathrm{Cr}$ increased the synthesis of fat in the adipose tissue and decreased the release of it. This might be acting through increased glucose flux into the adipocytes. Yildiz et al. (2004) exhibited that $\mathrm{Cr}$ supplementation from CrPic expanded serum insulin and total protein fixations as dietary $\mathrm{Cr}$ level expanded $(\mathrm{P} \leq 0.05)$. Also, expanded dietary chromium straightly expanded the insulin serum focus, showing the physiological part of chromium as an insulin cofactor engaging the insulin.

The relationship between chromium supplementation and insulin in the present study is in concurrence with those reported by (Colgan, 1993) who demonstrated that chromium a crucial for typical glucose digestion system and it is a part of glucose resistance element (GTF) which helps insulin to move glucose into cells for energy generation. Insulin additionally manages digestion system of carbohydrate, fat, and protein, stimulating amino acid uptake and protein synthesis amalgamation and glucose usage. Rosebrough and Steele,
(1981) stated that turkeys fed, diet supplemented with chromium had more prominent liver glycogen levels as an aftereffect of expanding action of the compound glycogen synthetase. Chromium is by and large acknowledged as the dynamic part in the glucose resilience component (GTF), which builds the affectability of tissue receptors to insulin, bringing about expanded glucose uptake by cells. Research recommends $\mathrm{Cr}$ contribution in starch digestion system including glucose uptake, glucose utilization for lipogenisis, and glycogen arrangement (Anderson et al., 1998). It was conjectured that expanded glucose uptake ought to build oxidation of glucose which would be generally changed over to unsaturated fats and put away as triglycerides in fat tissues. Al-Bandr, et al. (2010) found that blood calcium was not influenced essentially by including $\mathrm{Cr}$ into the diets. Sahin et al. (2002b) demonstrated that adding $\mathrm{Cr}$ to broiler diet expanded serum $\mathrm{Ca}$. A conceivable clarification for the impact of $\mathrm{Cr}$ supplementation on $\mathrm{Ca}$ digestion system might be because of that this mineral $(\mathrm{Cr})$ vie for the same restricting locales, so expanded $\mathrm{Cr}$ fixation bringing about a diminishing in liberating of restricting destinations on the exchanging, contended by the individual minerals. Separately or as a combination supplemental vit. $\mathrm{C}$ and $\mathrm{Cr}$ resulted in a decrease in MDA concentration (Tawfeek et al. 2014). Attia et al. (2015) reported that serum malonialdehyde (MDA) and cholesterol concentration decreased with dietary Cr. On the other hand, testosterone concentration level appeared was significantly higher in cocks. Testosterone is the most important androgen secreted into the blood. In males, testosterone is secreted primarily by the Leydig cells of the testes, whereas, it is in charge of the advancement of optional male sex qualities. Testosterone is expected to start spermatogenesis at pubescence and for the upkeep of this procedure in the grown-up. 
It additionally required for the assemblage of meiosis and for the separation of the spermatids (Poccia, 1994).

Results in Table 5 showed that SRBCs concentrations and blood testosterone were significantly $(\mathrm{P} \leq 0.05)$ influenced by interaction between dietary $\mathrm{Na}-\mathrm{B}$ and $\mathrm{Cr}$ at the end of experimental period. Moreover, serum total protein, albumin, insulin, cholesterol, T3 hormone, MDA and GPX values were not significanly influenced by these interactions.

\section{Semen physical characteristics of cocks and seminal malondialdehyde:}

It was clear that feeding diet containing Na-B at a level of 5 and $10 \mathrm{~g} / \mathrm{kg}$ diet had no significant difference among treatments in semen ejaculate volume. Moreover, percentage of sperm motility and sperm cell concentration were significantly $(\mathrm{P} \leq 0.05)$ increased when cockerels fed diets contained $\mathrm{Na}-\mathrm{B}$ as contrasted and those fed control diet. Such finding could recommend that bentonite may enhance the accessibility of supplements, including unsaturated fats (Abdl-Rahman et al. 2010); this pondering the level of blood lipids and thusly on its level in the fundamental liquid. While, $\mathrm{Na}-$ B supplementation to the diet demonstrated a lessening dead spermatozoa (\%) and seminal MDA contrasted and the control group (Table 5). Such finding could recommend that bentonite may enhance the accessibility of supplements, including unsaturated fats (Abdl-Rahman et al. 2010); this reflecting on the level of blood lipids and consequently on its level in the seminal fluid. The obtained results might attributed to the suggestion that $\mathrm{Na}-\mathrm{B}$ should have a stimulatory role on the digestion and absorption processes that consequently enhance nutrient availability reflecting positively on the synthetic pathways, including gonadal one. These results were in agreement with those obtained by semen attributes, including sperm wave movement, sperm motility and sperm fixation were seen with buck rabbits encouraged with normally aflatoxin (AF)diet in addition to bentonite contrasted with those nourished with AF-count calories alone. Nowar et al. (2000) who found that significant improvement $(\mathrm{P} \leq 0.01$ or 0.05$)$ in semen attributes, including sperm wave movement, sperm motility and sperm fixation were seen with buck rabbits encouraged with naturally aflatoxin (AF)diet addition bentonite contrasted with those fed with AF- diet alone. The magnitude of improvements in the semen qualities were acquired when bentonite was added at $1 \%$ to the aflatoxin contaminated diet.

The data revealed that cocks fed CrPic resulted in a significant $(\mathrm{P} \leq 0.05$ or $\mathrm{P} \leq 0.01)$ improvements in semen physical properties and seminal MDA level contrasted and those fed control diet (Table 5). These results might be because of chromium is an antioxidant and impacts lipid peroxidation by battling free radical harm in the body (Preuss et al., 1997). The improvement in semen quality of cocks might be because of a great level of testosterone hormone. The previous results revealed that high fertile cocks had a higher level of testosterone than the low fertile cocks, since the increase in testosterone hormone level increases the sexual desire. These outcomes are in understanding with Ezzat et al. (2009) who found that addition of chromium (1200 or $1800 \mu \mathrm{g} \mathrm{Cr} / \mathrm{kg}$ ) to cock diets significantly $(\mathrm{P} \leq 0.05$ and 0.01$)$ increase sperm motility (\%) and sperm-cell concentration and significantly $(\mathrm{P} \leq 0.05)$ decreased dead spermatozoa (\%) and sperm abnormalities (\%) for either Matrouh or Mandaraha cocks than control group and they found that these additions of chromium can improve the tests activity, consequently, the fertility and hatchability improved. Also, Hanafy (2011) reported a critical change in semen physical properties by $\mathrm{Cr}$ supplementation. Such change in semen physical properties might be because of the activity of cell reinforcement impact 
of chromium which lessened the oxidative harm and kept up. Similarly, Abdallah et al. (2013) demonstrated that $\mathrm{Cr}$ supplementation from CrPic significantly $(\mathrm{P} \leq 0.05)$ increased ejaculate volume, advanced motility and alive sperm (\%) contrasted and control group. The reduction in seminal MDA concentration might be due to the ability of $\mathrm{Cr}$ antioxidants in the supplementations to resist the lipid peroxidation damage in the spermatozoa. Moreover, there is a significant correlation between's expansion in MDA level and diminishing in fertility (Douard et al. 2003). Long and Kramer (2003) suggested that the reduced in seminal MDA concentration is an indicator about the degree of sperm membranes integrity and their fertilizing ability.

Sperm motility, dead spermatozoa and sperm cell concentration were significantly $(\mathrm{P} \leq 0.01)$ influenced by the interaction between dietary supplementation of $\mathrm{Na}-\mathrm{B}$ and $\mathrm{CrPic}$ levels. Whereas, semen ejaculate volume and sperm abnormalities (\%) were not significantly influenced by these interactions (Table 5).

Hatchability traits: Layers fed diets containing Na-B either at 5 and $10 \mathrm{~g} / \mathrm{kg}$ diet resulted in a higher Fertility eggs \% and hatchability/total eggs $(\mathrm{P} \leq 0.01$, $\mathrm{P} \leq 0.05)$ as contrasted and those fed control diet (Table 6). These results might be because of the good semen quality traits of the cocks treated with $\mathrm{Na}-\mathrm{B}$ and these results might be because of some minerals of bentonite and its biological values as well as bentonite can be a natural anticontamination of poultry feed (Khan et al., 2004). However, hatchability/fertility eggs $\%$ was not affected with Na-B at the end of experimental period. These result agreements with those reported by Fatouh et al. (2012) who stated that fertility, hatchability of total and fertile eggs of Domyati and Kampell ducks were significantly improved by feeding diets supplemented with 0.50 or $1.0 \% \mathrm{Na}-\mathrm{B}$ as compared to the control.

Results in Table (6) summarize CrPic supplementation levels significantly affected fertility eggs $\%$ and hatchability/ total eggs $\%$ of laying hens contrasted and those for control. However, hatchability/fertile eggs (\%) was insignificantly affected by $\mathrm{CrPic}$ supplementations. This might be because of the enhancement in semen characteristics as a consequence of $\mathrm{Cr}$ supplementation. These outcomes are in understanding by obtained with those of Ezzat et al. (2009) who found that adding chromium to the diets significantly $(\mathrm{P} \leq 0.01)$ increased fertility $(\%)$ and hatchability/total eggs (\%) for either Matrouh or Mandarah than untreated group through the entire period (overall mean). Moreover, Hanafy (2011) demonstrated that all the concentrations of dietary $\mathrm{Cr}(0,250,500,1000$ and $1500 \mathrm{ppb}$ of $\mathrm{Cr})$ significantly $(\mathrm{P} \leq 0.05)$ increased the fertility and hatchability percentages contrasted and those of the control. Also, Abdallah et al. (2013) demonstrated that all concentrations of dietary $\mathrm{Cr}$ supplementations $(0,200,400,600$ and 800 $\mu \mathrm{g}$ of $\mathrm{Cr} / \mathrm{kg}$ of diet) significantly $(\mathrm{P} \leq 0.05)$ increased the fertility and hatchability percentages contrasted and those of the control.

Values of fertility eggs $\%$ and hatchability/fertile eggs (\%) were significantly $(\mathrm{P} \leq 0.01)$ influenced by the interaction between dietary supplementation of $\mathrm{Na}-\mathrm{B}$ and $\mathrm{CrPic}$ levels. Whereas, hatchability/ total eggs \% was not significantly affected by these interactions.

\section{CONCLUSION}

Supplementing chicken diets with either $10 \mathrm{~g} \mathrm{Na}-\mathrm{B}$ or $1200 \mu \mathrm{g} \mathrm{CrPic} / \mathrm{kg}$ diet alone or together may improve most of the productive traits in addition to egg and semen quality, fertility, hatchability and blood parameters and in addition improved immune responses. 
Table (1): Composition and calculated analysis of the basal diet fed.

\begin{tabular}{|l|c|}
\hline \multicolumn{1}{|c|}{ Ingredients \% } & \% \\
\hline Yellow corn & 64.00 \\
Soybean meal 44 \% & 24.50 \\
Wheat bran & 1.50 \\
Di-calcium phosphate & 1.50 \\
Limestone & 7.70 \\
Salt (NaCl) & 0.40 \\
Dl-Methionine & 0.10 \\
Vit. \& Min. Mixture * & 0.30 \\
\hline Total & 100.00 \\
\hline Calculated analysis & \\
Metabolizable energy (Kcal / Kg ) & 2713.5 \\
Crude protein \% & 15.99 \\
Crude fiber \% & 3.46 \\
Crude fat \% & 2.96 \\
Calcium \% & 3.34 \\
Available phosphorous \% & 0.42 \\
Lysine \% & 0.89 \\
Methionine \% & 0.39 \\
Met+cystine \% & 0.66 \\
\end{tabular}

* Vitamins and minerals premix provides per 3kgVit.A 10000000 IU,Vit.D3 2000000 IU, Vit. E 10000mg,,Vit.K3 1000mg,Vit. B1 1000mg,Vit.B2 5000mg,Vit.B6 1500mg,Vit.B12 $10 \mathrm{mg}$, pantothenic acid $10000 \mathrm{mg}$,Niacin $30000 \mathrm{mg}$, Biotin $50 \mathrm{mg}$,Folic acid $1000 \mathrm{mg}$, Choline 250gm, Selenium 100mg, Copper 4000mg, Iron 30000mg, Manganese 60000mg, Zinc 50000mg, Iodine $1000 \mathrm{mg}$, Cobalt $100 \mathrm{mg}$ and $\mathrm{CaCO} 3$ to $3000 \mathrm{~g}$. 
Table (2): Body weight changes, feed intake and feed conversion $(\bar{X} \pm S E)$ of Matrouh layers as affected by different levels of dietary sodium bentonite and organic chromium and their interactions during the different experimental periods.

\begin{tabular}{|c|c|c|c|c|c|c|c|c|c|c|c|c|c|}
\hline \multirow{2}{*}{\multicolumn{2}{|c|}{ Items }} & \multicolumn{4}{|c|}{$\begin{array}{l}\text { Body weight changes } \\
\text { (gm) }\end{array}$} & \multicolumn{4}{|c|}{$\begin{array}{l}\text { Feed intake } \\
\text { (g/hen/day) }\end{array}$} & \multicolumn{4}{|c|}{ Feed conversion (g.feed/g.egg mass) } \\
\hline & & $\begin{array}{c}28- \\
32 \mathrm{Wk}\end{array}$ & $\begin{array}{c}32- \\
36 \mathrm{Wk}\end{array}$ & $\begin{array}{c}36- \\
40 \mathrm{Wk}\end{array}$ & $28-40 \mathrm{Wk}$ & $\begin{array}{c}28- \\
32 \mathrm{Wk}\end{array}$ & $\begin{array}{c}32- \\
36 \mathrm{Wk}\end{array}$ & $\begin{array}{c}36- \\
40 \mathrm{Wk}\end{array}$ & $\begin{array}{c}28- \\
40 \mathrm{Wk}\end{array}$ & $\begin{array}{c}28- \\
32 \mathrm{Wk}\end{array}$ & $\begin{array}{c}32- \\
36 \mathrm{Wk}\end{array}$ & $\begin{array}{c}36- \\
40 \mathrm{Wk}\end{array}$ & $\begin{array}{c}28- \\
40 \mathrm{Wk}\end{array}$ \\
\hline \multicolumn{2}{|c|}{ Na-B $(g / k g):$} & $*$ & NS & NS & $* *$ & NS & $*$ & $*$ & $*$ & $*$ & $* *$ & $* *$ & $* *$ \\
\hline \multicolumn{2}{|l|}{5} & $95.69^{\mathrm{a}}$ & 57.44 & 53.74 & $206.86^{\mathrm{a}}$ & 97.15 & $99.29^{\mathrm{b}}$ & $103.21^{\mathrm{b}}$ & $99.88^{\mathrm{b}}$ & $3.39^{\mathrm{b}}$ & $2.99^{\mathrm{b}}$ & $3.27^{\mathrm{b}}$ & $3.21^{\mathrm{b}}$ \\
\hline \multicolumn{2}{|l|}{10} & $97.81^{\mathrm{a}}$ & 61.36 & 54.45 & $213.62^{\mathrm{a}}$ & 95.40 & $98.83^{b}$ & $101.59^{\mathrm{b}}$ & $98.61^{\mathrm{b}}$ & $3.34^{\mathrm{b}}$ & $2.96^{\mathrm{b}}$ & $3.16^{\mathrm{b}}$ & $3.14^{\mathrm{b}}$ \\
\hline \multicolumn{2}{|c|}{ SEM } & 9.65 & 8.48 & 4.37 & 13.90 & 2.27 & 2.29 & 2.88 & 2.21 & 0.10 & 0.08 & 0.10 & 0.08 \\
\hline \multicolumn{2}{|c|}{$\mathrm{Cr} / \mathrm{Kg} \operatorname{diet}(\mu \mathrm{g})$. } & $* *$ & NS & NS & $* *$ & NS & NS & NS & NS & NS & NS & NS & NS \\
\hline \multicolumn{2}{|c|}{0} & $64.82^{\mathrm{b}}$ & 43.74 & 45.23 & $153.80^{\mathrm{c}}$ & 98.19 & 101.68 & 103.40 & 101.09 & 3.59 & 3.17 & 3.42 & 3.38 \\
\hline \multicolumn{2}{|l|}{800} & $96.73^{\mathrm{a}}$ & 49.74 & 48.63 & $195.09^{\mathrm{b}}$ & 99.30 & 100.03 & 105.94 & 101.76 & 3.43 & 3.01 & 3.37 & 3.26 \\
\hline \multicolumn{2}{|l|}{1200} & $101.46^{\mathrm{a}}$ & 67.61 & 57.38 & $226.46^{\mathrm{a}}$ & 99.29 & 103.81 & 107.75 & 103.62 & 3.50 & 3.10 & 3.37 & 3.31 \\
\hline \multicolumn{2}{|l|}{ SEM } & 9.10 & 7.89 & 4.53 & 13.19 & 2.46 & 2.65 & 3.27 & 2.63 & 0.12 & 0.09 & 0.14 & 0.11 \\
\hline \multicolumn{2}{|c|}{ Interaction effects: } & $*$ & NS & NS & $* *$ & NS & NS & NS & NS & NS & NS & NS & NS \\
\hline $\begin{array}{l}\mathrm{Na}-\mathrm{B} \\
(\mathrm{g} / \mathrm{kg})\end{array}$ & $\begin{array}{c}\mathrm{Cr} / \mathrm{Kg} \\
(\mu \mathrm{g})\end{array}$ & & & & & & & & & & & & \\
\hline \multirow[t]{3}{*}{0} & 800 & $74.65^{\mathrm{cd}}$ & 50.57 & 48.04 & $173.26^{\mathrm{cb}}$ & 105.20 & 104.02 & 112.03 & 107.08 & 3.82 & 3.25 & 3.66 & 3.57 \\
\hline & 1200 & $88.02^{\mathrm{abcd}}$ & 43.35 & 43.30 & $174.67^{\mathrm{cb}}$ & 103.73 & 108.48 & 117.42 & 109.88 & 3.70 & 3.38 & 3.91 & 3.65 \\
\hline & 0 & $78.02^{\mathrm{bcd}}$ & 64.89 & 44.63 & $187.54^{\mathrm{cb}}$ & 94.47 & 96.75 & 98.29 & 96.50 & 3.49 & 3.02 & 3.22 & 3.23 \\
\hline \multirow[t]{3}{*}{5} & 800 & $120.81^{\mathrm{ab}}$ & 35.34 & 51.88 & $208.04^{\mathrm{cb}}$ & 98.56 & 95.91 & 108.27 & 100.91 & 3.18 & 2.85 & 3.40 & 3.14 \\
\hline & 1200 & $88.24^{\text {abcd }}$ & 72.08 & 64.70 & $225.02^{\mathrm{b}}$ & 98.41 & 105.21 & 103.07 & 102.23 & 3.51 & 3.09 & 3.17 & 3.25 \\
\hline & 0 & $70.59^{\mathrm{cd}}$ & 33.38 & 53.22 & $157.19^{\text {cd }}$ & 96.31 & 98.59 & 104.49 & 99.80 & 3.42 & 3.14 & 3.38 & 3.31 \\
\hline \multirow[t]{2}{*}{10} & 800 & $94.72^{\mathrm{abc}}$ & 63.30 & 45.97 & $203.98^{\mathrm{cb}}$ & 94.15 & 100.16 & 97.51 & 97.27 & 3.29 & 2.92 & 3.06 & 3.08 \\
\hline & 1200 & $128.13^{\mathrm{a}}$ & 87.41 & 64.15 & $279.68^{\mathrm{a}}$ & 95.73 & 97.75 & 102.76 & 98.75 & 3.31 & 2.81 & 3.03 & 3.04 \\
\hline \multicolumn{2}{|l|}{ SEM } & 13.78 & 8.56 & 6.21 & 12.55 & 4.25 & 4.41 & 4.89 & 4.37 & 0.17 & 0.13 & 0.14 & 0.14 \\
\hline
\end{tabular}

Means having different letters at the same column are differ significantly. $\quad *=(\mathrm{P}<0.05), \quad * *=(\mathrm{P}<0.01) ; \quad$ NS= Not significant 
Table (3): Egg weight, egg production and egg mass $(\bar{X} \pm S E)$ of Matrouh layers as affected by different levels of dietary and organic and their interactions during the different experimental periods.

\begin{tabular}{|c|c|c|c|c|c|c|c|c|c|c|c|c|c|}
\hline \multirow{2}{*}{\multicolumn{2}{|c|}{ Items }} & \multicolumn{4}{|c|}{ Egg weight ( g) } & \multicolumn{4}{|c|}{ Egg production \% } & \multicolumn{4}{|c|}{ Egg mass (g/hen) } \\
\hline & & $\begin{array}{c}28- \\
32 W k\end{array}$ & $\begin{array}{c}32- \\
36 \mathrm{Wk}\end{array}$ & $\begin{array}{c}36- \\
40 \mathrm{Wk}\end{array}$ & $\begin{array}{c}28- \\
40 \mathrm{Wk}\end{array}$ & $\begin{array}{c}28- \\
32 \mathrm{Wk}\end{array}$ & $\begin{array}{c}32- \\
36 \mathrm{Wk}\end{array}$ & $36-40 \mathrm{Wk}$ & $\begin{array}{c}28- \\
40 W k\end{array}$ & $\begin{array}{c}28- \\
32 \mathrm{Wk}\end{array}$ & $\begin{array}{c}32- \\
36 \mathrm{Wk}\end{array}$ & $\begin{array}{c}36- \\
40 \mathrm{Wk}\end{array}$ & $\begin{array}{c}28- \\
40 W k\end{array}$ \\
\hline \multicolumn{2}{|c|}{ SB $(g / k g):$} & $* *$ & $* *$ & $*$ & $* *$ & NS & NS & $* *$ & $*$ & $*$ & $*$ & $* *$ & $* *$ \\
\hline \multicolumn{2}{|c|}{0} & $46.16^{\mathrm{b}}$ & $48.39^{b}$ & $48.46^{\mathrm{b}}$ & $47.67^{\mathrm{c}}$ & 59.60 & 66.79 & $61.94^{\mathrm{b}}$ & $62.78^{b}$ & $27.51^{\mathrm{b}}$ & $32.30^{\mathrm{b}}$ & $30.01^{\mathrm{b}}$ & $29.92^{b}$ \\
\hline \multicolumn{2}{|c|}{5} & $46.59^{a}$ & $48.60^{\mathrm{b}}$ & $48.78^{a b}$ & $47.99^{\mathrm{b}}$ & 61.71 & 68.37 & $64.92^{\mathrm{a}}$ & $65.00^{\mathrm{a}}$ & $28.77^{\text {a }}$ & $33.23^{\mathrm{a}}$ & $31.67^{\mathrm{a}}$ & $31.20^{\mathrm{a}}$ \\
\hline & $46.77^{\mathrm{a}}$ & $49.13^{\mathrm{a}}$ & $49.03^{\mathrm{a}}$ & $48.31^{\mathrm{a}}$ & 61.19 & 68.13 & $65.71^{\mathrm{a}}$ & $65.01^{\mathrm{a}}$ & $28.62^{\mathrm{a}}$ & $33.49^{\mathrm{a}}$ & $32.22^{\mathrm{a}}$ & $31.41^{\mathrm{a}}$ \\
\hline \multicolumn{2}{|c|}{ SEM } & 0.17 & 0.30 & 0.28 & 0.13 & 0.89 & 0.78 & 0.89 & 0.70 & 0.45 & 0.42 & 0.46 & 0.34 \\
\hline \multirow{2}{*}{\multicolumn{2}{|c|}{$\begin{array}{l}\mathrm{Cr} / \mathrm{Kg} \operatorname{diet}(\mu \mathrm{g}) \text {. } \\
0\end{array}$}} & NS & NS & $*$ & $* *$ & $*$ & $*$ & $*$ & $* *$ & $*$ & $* *$ & $* *$ & $* *$ \\
\hline & & $46.38^{\mathrm{b}}$ & 48.54 & $48.47^{\mathrm{b}}$ & $47.80^{\mathrm{b}}$ & $59.13^{\mathrm{b}}$ & $66.11^{\mathrm{b}}$ & $62.42^{\mathrm{b}}$ & $62.55^{\mathrm{b}}$ & $27.42^{\mathrm{b}}$ & $32.09^{b}$ & $30.26^{\mathrm{b}}$ & $29.90^{\mathrm{b}}$ \\
\hline \multicolumn{2}{|c|}{800} & $46.43^{a b}$ & 48.62 & $48.79^{\mathrm{ab}}$ & $47.95^{b}$ & $62.62^{a}$ & $68.49^{a}$ & $64.52^{a b}$ & $65.21^{\mathrm{a}}$ & $29.08^{\mathrm{a}}$ & $33.30^{\mathrm{a}}$ & $31.46^{\mathrm{a}}$ & $31.26^{\mathrm{a}}$ \\
\hline \multicolumn{2}{|l|}{1200} & $46.72^{\mathrm{a}}$ & 48.96 & $49.01^{\mathrm{a}}$ & $48.23^{\mathrm{a}}$ & $60.75^{\mathrm{ab}}$ & $68.69^{\mathrm{a}}$ & $65.63^{\mathrm{a}}$ & $65.03^{\mathrm{a}}$ & $28.39^{\mathrm{ab}}$ & $33.63^{\mathrm{a}}$ & $32.18^{\mathrm{a}}$ & $31.37^{\mathrm{a}}$ \\
\hline \multicolumn{2}{|c|}{ SEM } & 0.18 & 0.32 & 0.28 & 0.16 & 0.77 & 0.70 & 0.94 & 0.62 & 0.42 & 0.40 & 0.47 & 0.32 \\
\hline \multicolumn{2}{|c|}{$\begin{array}{l}\text { Interaction } \\
\text { effects: }\end{array}$} & $* *$ & $* *$ & $* *$ & $* *$ & NS & NS & NS & NS & $*$ & $* *$ & NS & $*$ \\
\hline \multirow[t]{2}{*}{$\begin{array}{c}\mathrm{SB} \\
(\mathrm{g} / \mathrm{kg})\end{array}$} & $\begin{array}{l}\mathrm{Cr} / \mathrm{Kg} \\
(\mu \mathrm{g})\end{array}$ & & & & & & & & & & & & \\
\hline & 0 & $45.88^{\mathrm{e}}$ & $49.58^{\mathrm{a}}$ & $47.91^{\mathrm{cd}}$ & $47.79^{c}$ & 58.69 & 66.19 & 61.07 & 61.98 & $26.92^{c}$ & $32.81^{\mathrm{bcd}}$ & 29.25 & $29.62^{b}$ \\
\hline \multirow[t]{3}{*}{0} & 800 & $45.73^{\mathrm{e}}$ & $48.04^{\mathrm{b}}$ & $49.75^{\mathrm{ab}}$ & $47.84^{c}$ & 60.24 & 66.67 & 61.67 & 62.86 & $27.54^{\mathrm{bc}}$ & $32.00^{\mathrm{cd}}$ & 30.67 & $30.06^{\mathrm{b}}$ \\
\hline & 1200 & $46.87 \mathrm{abc}$ & $47.56^{\mathrm{b}}$ & $47.72^{\mathrm{d}}$ & $47.38^{\mathrm{d}}$ & 59.88 & 67.50 & 63.10 & 63.49 & $28.07^{b c}$ & $32.08^{\mathrm{cd}}$ & 30.11 & $30.08^{\mathrm{b}}$ \\
\hline & 0 & $46.08^{\mathrm{de}}$ & $47.63^{\mathrm{b}}$ & $48.28^{\mathrm{cd}}$ & $47.33^{\mathrm{d}}$ & 58.93 & 67.26 & 63.33 & 63.17 & $27.16^{\mathrm{bc}}$ & $32.04^{\mathrm{cd}}$ & 30.58 & $29.90^{\mathrm{b}}$ \\
\hline \multirow[t]{3}{*}{5} & 800 & $47.09^{\mathrm{ab}}$ & $48.36^{\mathrm{b}}$ & 48.07 & $47.84^{c}$ & 65.95 & 69.52 & 66.31 & 67.26 & $31.06^{\mathrm{a}}$ & $33.61^{\mathrm{abc}}$ & 31.86 & $32.18^{\mathrm{a}}$ \\
\hline & 1200 & $46.59^{\text {bcd }}$ & $49.82^{\mathrm{a}}$ & $50.00^{\mathrm{a}}$ & $48.80^{\mathrm{a}}$ & 60.24 & 68.33 & 65.12 & 64.56 & $28.07^{\mathrm{bc}}$ & $34.05^{\mathrm{ab}}$ & 32.56 & $31.51^{\mathrm{a}}$ \\
\hline & 0 & $47.17^{\mathrm{a}}$ & $48.41^{\mathrm{b}}$ & $49.23^{b}$ & $48.27^{\mathrm{b}}$ & 59.76 & 64.88 & 62.86 & 62.50 & $28.19^{b c}$ & $31.41^{\mathrm{d}}$ & 30.95 & $30.17^{b}$ \\
\hline \multirow[t]{2}{*}{10} & 800 & $46.45^{\text {cd }}$ & $49.47^{\mathrm{a}}$ & $48.55^{\mathrm{c}}$ & $48.16^{\mathrm{bc}}$ & 61.67 & 69.29 & 65.60 & 65.52 & $28.65^{\mathrm{bc}}$ & $34.28^{\mathrm{ab}}$ & 31.84 & $31.55^{\mathrm{a}}$ \\
\hline & 1200 & $46.68^{a b c}$ & $49.52^{\mathrm{a}}$ & $49.30^{b}$ & $48.50^{\mathrm{ab}}$ & 62.14 & 70.24 & 68.69 & 67.02 & $29.01^{b}$ & $34.78^{a}$ & 33.86 & $32.51^{\mathrm{a}}$ \\
\hline \multicolumn{2}{|l|}{ SEM } & 0.08 & 0.16 & 0.26 & 0.08 & 1.15 & 1.05 & 1.26 & 0.72 & 0.62 & 0.38 & 0.33 & 0.19 \\
\hline
\end{tabular}


Table (4): Egg quality and egg components $(\bar{X} \pm S E)$ of Matrouh layers as affected by different levels of dietary and organic and their interactions during the different experimental periods.

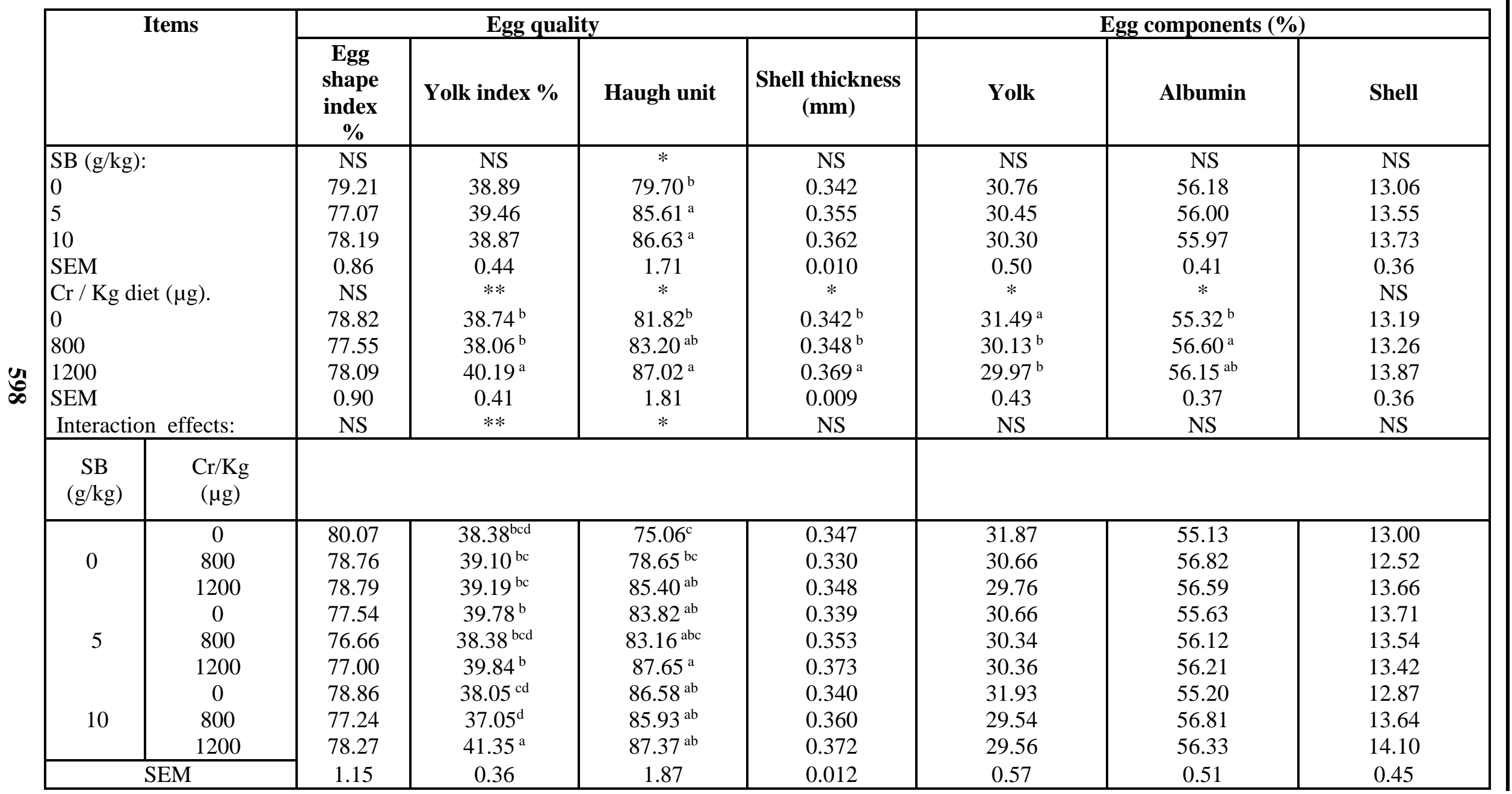

Means having different letters at the same column are differ significantly. $\quad *=(\mathrm{P}<0.05), \quad * *=(\mathrm{P}<0.01) ; \mathrm{NS}=\mathrm{Not}$ significant 
Table (5): Antibody response and blood constituents $(\bar{X} \pm S E)$ of Matrouh layers and blood testosterone of cocks as affected by different levels of dietary and organic and their interactions during the different experimental periods.

\begin{tabular}{|c|c|c|c|c|c|c|c|c|c|c|c|}
\hline \multicolumn{2}{|l|}{ Items } & SRBCs & $\begin{array}{c}\text { Total } \\
\text { protein } \\
\text { (g/dl) }\end{array}$ & $\begin{array}{l}\text { Albumin } \\
\text { (g/dl) }\end{array}$ & $\begin{array}{l}\text { Insulin } \\
(\mathbf{n g} / \mathbf{m l})\end{array}$ & $\begin{array}{c}\text { Cholesterol } \\
(\mathrm{mg} / \mathrm{dl})\end{array}$ & $\begin{array}{c}\text { Calcium } \\
\text { (mg/dl) }\end{array}$ & T3 & MDA & GPX & Testosterone \\
\hline \multicolumn{2}{|c|}{ SB $(\mathrm{g} / \mathrm{kg}):$} & NS & NS & NS & NS & $*$ & $*$ & NS & $* *$ & $* *$ & $* *$ \\
\hline \multicolumn{2}{|c|}{0} & 3.48 & 5.58 & 2.98 & 0.182 & $154.06^{\mathrm{a}}$ & $12.37^{\mathrm{b}}$ & 3.07 & $3.39^{\mathrm{a}}$ & $43.79^{b}$ & $1.72^{b}$ \\
\hline \multicolumn{2}{|c|}{5} & 3.53 & 5.98 & 3.29 & 0.196 & $145.28^{a b}$ & $12.83^{\mathrm{ab}}$ & 3.09 & $3.01^{\mathrm{a}}$ & $47.72^{\mathrm{a}}$ & $1.95^{\mathrm{a}}$ \\
\hline \multicolumn{2}{|l|}{10} & 3.64 & 6.01 & 3.30 & 0.212 & $141.94^{\mathrm{b}}$ & $13.14^{\mathrm{a}}$ & 3.13 & $2.38^{\mathrm{b}}$ & $48.79^{a}$ & $2.03^{\mathrm{a}}$ \\
\hline \multicolumn{2}{|c|}{ SEM } & 0.13 & 0.18 & 0.15 & 0.015 & 5.41 & 0.22 & 0.13 & 0.18 & 1.04 & 0.08 \\
\hline \multirow{2}{*}{\multicolumn{2}{|c|}{$\begin{array}{l}\mathrm{Cr} / \mathrm{Kg} \operatorname{diet}(\mu \mathrm{g}) \text {. } \\
0\end{array}$}} & $* *$ & $* *$ & $* *$ & $*$ & $* *$ & $*$ & NS & NS & NS & $* *$ \\
\hline & & $3.20^{\mathrm{c}}$ & $5.43^{\mathrm{b}}$ & $2.83^{b}$ & $0.161^{\mathrm{b}}$ & $157.61^{\mathrm{a}}$ & $12.30^{\mathrm{b}}$ & 2.89 & 3.13 & 48.28 & $1.70^{\mathrm{b}}$ \\
\hline \multicolumn{2}{|l|}{800} & $3.48^{\mathrm{b}}$ & $5.99^{\mathrm{a}}$ & $3.41^{\mathrm{a}}$ & $0.211^{\mathrm{a}}$ & $146.44^{\mathrm{b}}$ & $12.97^{\mathrm{a}}$ & 3.15 & 2.92 & 45.92 & $1.95^{\mathrm{a}}$ \\
\hline \multicolumn{2}{|l|}{1200} & $3.98^{\mathrm{a}}$ & $6.14^{\mathrm{a}}$ & $3.32^{\mathrm{a}}$ & $0.218^{\mathrm{a}}$ & $137.22^{\mathrm{b}}$ & $13.07^{\mathrm{a}}$ & 3.25 & 2.74 & 46.10 & $2.05^{\mathrm{a}}$ \\
\hline \multicolumn{2}{|c|}{ SEM } & 0.07 & 0.16 & 0.12 & 0.013 & 3.47 & 0.22 & 0.12 & 0.23 & 1.22 & 0.07 \\
\hline \multicolumn{2}{|c|}{$\begin{array}{l}\text { Interaction } \\
\text { effects: }\end{array}$} & $*$ & NS & NS & NS & NS & NS & NS & NS & NS & $*$ \\
\hline \multirow[t]{2}{*}{$\begin{array}{c}\mathrm{SB} \\
(\mathrm{g} / \mathrm{kg})\end{array}$} & $\begin{array}{c}\mathrm{Cr} / \mathrm{Kg} \\
(\mu \mathrm{g})\end{array}$ & & & & & & & & & & \\
\hline & 0 & $3.34^{\mathrm{de}}$ & 5.42 & 2.83 & 0.151 & 158.50 & 12.44 & 2.70 & 3.56 & 47.41 & $1.62^{\mathrm{d}}$ \\
\hline \multirow[t]{3}{*}{0} & 800 & $3.37^{\mathrm{de}}$ & 5.49 & 2.98 & 0.195 & 154.50 & 12.27 & 3.18 & 3.41 & 42.01 & $1.80^{\mathrm{bcd}}$ \\
\hline & 1200 & $3.74^{\mathrm{bc}}$ & 5.82 & 3.13 & 0.201 & 149.17 & 12.41 & 3.34 & 3.22 & 41.95 & $1.73^{\mathrm{cd}}$ \\
\hline & 0 & $3.11^{\mathrm{e}}$ & 5.31 & 2.87 & 0.162 & 157.83 & 12.27 & 2.84 & 3.26 & 47.80 & $1.65^{\mathrm{d}}$ \\
\hline \multirow[t]{3}{*}{5} & 800 & $3.48^{\mathrm{cd}}$ & 6.39 & 3.66 & 0.209 & 143.00 & 13.19 & 3.31 & 3.02 & 48.59 & $2.04^{\mathrm{ab}}$ \\
\hline & 1200 & $3.99^{\mathrm{ab}}$ & 6.24 & 3.35 & 0.215 & 135.00 & 13.04 & 3.11 & 2.75 & 46.78 & $2.17^{\mathrm{a}}$ \\
\hline & 0 & $3.15^{\mathrm{e}}$ & 5.57 & 2.79 & 0.170 & 156.50 & 12.20 & 3.13 & 2.57 & 49.63 & $1.82^{\mathrm{bcd}}$ \\
\hline \multirow[t]{2}{*}{10} & 800 & $3.58^{\mathrm{cd}}$ & 6.09 & 3.60 & 0.227 & 141.83 & 13.47 & 2.98 & 2.32 & 47.18 & $2.01^{\mathrm{abc}}$ \\
\hline & 1200 & $4.20^{\mathrm{a}}$ & 6.36 & 3.50 & 0.238 & 127.50 & 13.76 & 3.29 & 2.25 & 49.57 & $2.25^{\mathrm{a}}$ \\
\hline SEM & & 0.10 & 0.26 & 0.21 & 0.023 & 5.41 & 0.32 & 0.21 & 0.33 & 1.72 & 0.09 \\
\hline
\end{tabular}


Table(6): Physical Semen characteristics of cocks and seminal malondialdehyde and fertility and hatchability percentages $(\bar{X} \pm S E)$ of Matrouh chickens as affected by different levels of dietary sodium bentonite and organic chromium and their interactions at 36 weeks of age.

\begin{tabular}{|c|c|c|c|c|c|c|c|c|c|c|}
\hline \multicolumn{2}{|c|}{ Items } & \begin{tabular}{|c|}
$\begin{array}{c}\text { Ejaculate } \\
\text { volume } \\
(\mathrm{ml})\end{array}$ \\
\end{tabular} & $\begin{array}{c}\text { Sperm } \\
\text { motility } \\
(\%)\end{array}$ & $\begin{array}{c}\begin{array}{c}\text { Dead } \\
\text { spermatozoa } \\
(\%)\end{array} \\
\end{array}$ & \begin{tabular}{|c|} 
Sperm \\
abnormalities \\
$(\%)$
\end{tabular} & \begin{tabular}{|c|} 
Sperm cell \\
concentration \\
$(\mathrm{X} \mathrm{10} / \mathrm{ml})$
\end{tabular} & $\begin{array}{c}\text { Malondialdehyde } \\
(\mathrm{nmol} / \mathrm{ml})\end{array}$ & $\begin{array}{l}\text { Fertility } \\
\text { eggs \% }\end{array}$ & $\begin{array}{l}\text { Hatchability/ } \\
\text { Total eggs \% }\end{array}$ & $\begin{array}{c}\text { Hatchability/ } \\
\text { Fertility } \\
\text { eggs \% }\end{array}$ \\
\hline \multicolumn{2}{|c|}{ SB $(\mathrm{g} / \mathrm{kg}):$} & NS & $* *$ & $*$ & * & $* *$ & $*$ & $* *$ & $*$ & $\mathrm{NS}$ \\
\hline \multicolumn{2}{|c|}{5} & 0.31 & $91.22^{b}$ & $9.22^{\mathrm{ab}}$ & $5.78^{a}$ & $3.13^{\mathrm{a}}$ & $0.62^{a b}$ & 92.20 & 81.52 & 88.47 \\
\hline \multicolumn{2}{|l|}{10} & 0.29 & $96.00^{\mathrm{a}}$ & $8.00^{\mathrm{b}}$ & $4.78^{\mathrm{b}}$ & $3.37^{\mathrm{a}}$ & $0.57^{\mathrm{b}}$ & 93.96 & 84.73 & 90.22 \\
\hline \multicolumn{2}{|c|}{ SEM } & & 1.29 & 0.63 & 0.37 & 0.20 & 0.02 & 0.48 & 0.39 & 0.56 \\
\hline \multicolumn{2}{|l|}{800} & $0.26^{\mathrm{b}}$ & $93.56^{\mathrm{a}}$ & $9.56^{\mathrm{a}}$ & $6.44^{\mathrm{a}}$ & $3.23^{\mathrm{a}}$ & $0.57^{\mathrm{b}}$ & 92.81 & 82.97 & 89.42 \\
\hline \multicolumn{2}{|l|}{1200} & $0.29^{\mathrm{ab}}$ & $95.67^{\mathrm{a}}$ & $7.56^{\mathrm{b}}$ & $4.78^{\mathrm{b}}$ & $3.53^{\mathrm{a}}$ & $0.59^{b}$ & 93.17 & 84.32 & 90.66 \\
\hline \multicolumn{2}{|c|}{ SEM } & & 1.13 & 0.55 & 0.32 & 0.16 & 0.02 & 0.36 & 0.67 & 0.57 \\
\hline \multicolumn{2}{|c|}{$\begin{array}{l}\text { Interaction } \\
\text { effects: }\end{array}$} & NS & $*$ & $*$ & NS & $*$ & NS & $* *$ & NS & $*$ \\
\hline $\begin{array}{c}\mathrm{SB} \\
(\mathrm{g} / \mathrm{kg})\end{array}$ & $\begin{array}{c}\mathrm{Cr} / \mathrm{Kg} \\
(\mu \mathrm{g})\end{array}$ & & & & & & & & & \\
\hline \multirow[t]{3}{*}{5} & 800 & 0.27 & $91.67^{\mathrm{ab}}$ & $10.33^{\mathrm{ab}}$ & 6.67 & $3.38^{a b c}$ & 0.58 & $93.83^{\mathrm{ab}}$ & 83.33 & $88.72^{\mathrm{ab}}$ \\
\hline & 1200 & 0.27 & $95.33^{\mathrm{a}}$ & $7.67^{b c}$ & 4.67 & $3.57^{\mathrm{ab}}$ & 0.60 & $91.36^{\mathrm{ab}}$ & 85.19 & $93.45^{\mathrm{a}}$ \\
\hline & 0 & 0.27 & $96.00^{\mathrm{a}}$ & $7.67^{b c}$ & 4.00 & $2.59^{\mathrm{de}}$ & 0.64 & $93.70^{\mathrm{ab}}$ & 85.68 & $91.41^{\mathrm{a}}$ \\
\hline \multirow[t]{2}{*}{10} & 800 & 0.27 & $95.67^{\mathrm{a}}$ & $8.67^{b c}$ & 5.33 & $3.59^{\mathrm{ab}}$ & 0.53 & $93.86^{\mathrm{ab}}$ & 83.46 & $88.96^{\mathrm{ab}}$ \\
\hline & 1200 & 0.33 & $96.33^{\mathrm{a}}$ & $7.67^{b c}$ & 5.00 & $3.94^{\mathrm{a}}$ & 0.54 & $94.32^{\mathrm{a}}$ & 85.06 & $90.31^{\mathrm{a}}$ \\
\hline \multicolumn{2}{|c|}{ SEM } & & 1.18 & 0.71 & 0.39 & 0.17 & 0.03 & 0.54 & 0.33 & 0.50 \\
\hline
\end{tabular}




\section{REFERENCES}

Abd El-Samee, L. D.; El-Wardany, I.; Ali, NG. and Abo-El-Azab, O.M., 2012. Egg quality, fertility and hatchability of laying quails fed diets supplemented with organic zinc, $\mathrm{Cr}$ yeast or mannan oligosaccharides. Int J. Poult. Sci.,11(3): 221-224.

Abdallah, E. A.; Abdel Samad, M.H. and Abdel latif, A.M., 2013. Effect of supplementing diet with chromium picolinate on productive, reproductive, physiological performance and immune responseof golden montazah chickens. Egypt. Poult. Sci., Vol (33) (IV): 751-767.

Abdel-Mageed, M.A.A. and Hassan A. Hanan, 2012. Effect of chromium methionine chelate on performance and some plasma constituents of laying Japanese quail during summer months. Egypt. Poult. Sci., Vol (32) (IV): 883- 894.

Abdel-Motelib, A.; Kader Zainab Abdel; Ragab, Y.A. and Maha Mosalamy, 2001. Suitability of a miocene bentonite from north western desert of Egypt for pharmaceutical use. Applied Clay Sci., 52 :140-144.

Abdl-Rahman, M. A.; Sawiress, F. A. R. and Sohair Y. Saleh, 2010. Effect of Kemzyme - Bentonite Cosupplementation on Cecal Fermentation and Metabolic Pattern in Rabbit. J. of Agric. Sci., Vol. 2, No. 3.

Al-Bandr K. Luma; Dhia K. Ibrahim and Essa H. Al-Mashhadani, 2010. Effect of supplementing different sources of chromium to diet on some physiological traits of broiler chickens. Egypt. Poult. Sci., Vol (30) (II): 397-413.

El-Abd M. Niamat, 2014. Effect of feed supplemented with different levels of sodium bentonite on Japanese quail performance. Egypt. Poult. Sci., Vol (34) (III): 705-713.
Anderson, R. A., 1994. Stress effects on chromium nutrition of humans and farm Anim.s. In: Biotechnology in the Feed Industry (Lyons, T. P. \& Jacques, K. A., eds.), pp. 267-274. University Press, Nottingham, UK.

Anderson, R.A., 1998. Chromium, glucose intolerance and diabetes. J. Am. Coll. Nutr., 17, 548-555.

Anderson, R.A., 1999. Chromium as an essential nutrient. The chromium file from the International Development Association N.6 September 45 Rue de Lisbone, 75008 Paris.

Attia Kh. M; Tawfeek, F. A.; Mady, M. S. and Assar M.H., 2015. Effect of dietary chromium, selenium and vitamin c on productive performance and some blood parameters of local strain dokki-4 under Egyptian summer conditions. Egypt. Poult. Sci., Vol (35) (I): 311-329.

Colgan, M., 1993. Chromium boosts insulin efficiency. In: Optimum Sports

Nutrition. New York: Advanced Research Press, 1993. p. 313- 20.

Damiri, H.; Chaji, M.; Bojarpour M.; Eslami M. and Mamoei M., 2010. The effect of sodium betonites on economic value of broiler chickens diet. J. of Anim. and Vet Advances. 9:266826670.

Damiri, H.; Chaji, M.; Bojarpour M.; Eslami M. and Mamoei M., 2012. Effect of different sodium bentonite levels on performance, carcass traits and passage rate of broilers. Pak Vet J., 32(2): 197-200.

Davison, T. F., 2003. The immunologists' debt to the chicken. Br. Poult. Sci., 44:6-21.

Desheng, Q.; Fan, L.; Yanhu, Y. and Niya Z. (2005) . Adsorption of aflatoxin B1 on montmorillonite. Poult. Sci., 84 : 959-961.

Dorr, P. and Balloun, S. L., 1976. Effect of dietary vitamin A, ascorbic acid and their interaction on turkey bone mineralization. Br. Poult. Sci., 17: 581599. 
Douard, W.; Hermier, D.; Magistrini, M. and Blesbois, E. 2003. Reproductive period affects lipid composition and quality of fresh and stored spermatozoa in turkeys. Theriogenology 59: 753-764.

Duncan, D.B., 1955.Multiple range and multiple F tests. Biometrics, 11:1-42.

El-Hommosany, Y.M.,2008. Study of the physiological changes in blood chemistry, humoral immune response and performance of quail chicks fed supplemental chromium. Int J. of Poult Sci., 7 (1): 40-44.

Eraslan, G; Essiz, D; Akdogan, M.; Sahindokuyucu, F.; Altintas, L. andHismiogullari, S. E., (2005). Effects of dietary aflatoxin and sodium bentonite on some hormones in broiler chickens. Bull Vet Inst Pulawy 49: 93-96.

Eseceli, H.; Degirmencioglu, N.; and Bilgic, M., (2010). The effect of inclusion of organic chromium (CoFactor II, Alltech Inc.) and folic acid to the rations of laying hens on performance, egg quality, egg yolk cholesterol, folic acid and chromium levels. J. Anim. Vet. Advan. 9:384-391.

Ezzat, W.; Al-Kotait, A.H.A.; Bealish, A.M.A. and Mousa, S.M.M., 2009. Efficacy of chromium supplementation to alleviating the negative effects of heat stress on fertility of egg, semen quality and some physiological parameters in male Matrouh and Mandaraha Local strains reared in summer season of Egypt. Egypt. J. Nut. \& Feeds Sci., Vol (12) (3): 739-760.

Ezzat, W.;. El-Koteat A.H.A.; and Shoeib, M.S., 2006. Growth performance, digestibility, carcass traits and some blood constituents, of Japanese quails as affected by supplement of chromium in growing rations. J. Product. and Dev.,11(2): 351-366.

Fatouh, M. H. A.; Awad A. L.; and Ghonim, A. I. A. 2012. Effect of dietary sodium bentonite supplementation on laying performance of Domyati and Kampell ducks. Egypt. Poult. Sci., Vol (32) (III): (497-514).

Gilani, A; Kermanshahi, H.; Golian, A.; Tahmasbi, A. and Aami Azghadi, M. 2013. Appraisal of hematological indices and humoral immunity in commercial laying hens fed rations consisting cottonseed meal and sodium bentonite. Iranian J. of Applied Anim. Sci., Vol(3): 4: 803-809.

Hanafy, Maysa M. 2011. Influence of adding organic chromium in diet on productive traits, serum constituents and immune status of bandarah layinghens and semen physical properties for cocks in winter season. Egypt. Poult. Sci., Vol (31) (II): (203-216).

Hashemipour, H.; Kermanshahi, H. and Pilevar, M., 2010. Interactive effect of sodium bentonite with pigments on performance and egg quality of laying hens . J. of Anim. And Vet. Advances ,9 (16) : 2179-2184.

Haugh, R. R., (1937). The Haugh unit for measuring egg quality. United States . Egg Poult. Magazine, 43: 572- 573.

Hossain, S. M. (1998). Organic chromium in poultry: Metabolic responses, effects on broiler carcass composition, nutrient composition of eggs. In: Lyons, T.P. and K.A. Jacques (Eds.). Biotechnology in the Feed Industry. Nottingham University Press, Nottingham, UK 203-216.

Inal, F. ; Gulsen, N. ; Coskun, B. and Arslan C., 2000 . The effects of bentonite on egg performance of laying hens. Indian J. of Anim. Sci., 70, 194196.

Khan, A.D.; Ahmad, R.; Shahzad, K. and Saeed, S., 2004. Bentonites in poultry feed. Proc. Int. Nut. Conf. Hotel Pearl Continental, Lahore-Pak. December 1-2, 2004; 127.

Khanedar, I.; Vakili, R. and Zakizadeh S., 2012. Effects of two kinds of bentonite on the performance, blood biochemical parameters, carcass 
characteristics and tibia ash of broiler chicks. Global Vet., 9 (6): 720-725.

Kim, J. D.; Han, I. K.; Chae, B. J.; Lee, J. H.; Park, J. H. and Yang, C. J., 1997. Effects of dietary chromium picolinate on performance, egg quality, serum traits and mortality rate of brown layers. Asian Austr. J. Anim. Sci. 10: 1-7.

Lake, P. E. and Stewart, J. M., 1978. Artificial insemination in poultry. Agric. Fish. Fd. Bulletin, No. 213. H. M. Stationery Office, London.

Lien, T. F.; Yang, K. H. and Lin, K. J., 2005. Effect of chromium propionate supplementation on growth performance, serum traits and immune response in weaned pigs. Asian Austr. J. Anim. Sci., 18: 403- 408.

Long, J. A. and Kramer, M., 2003. Effect of vitamin $\mathrm{E}$ on lipid peroxidation and fertility after artificial insemination with liquid-stored turkey semen. Poult. Sci., 82: 1802-1807.

Mc Namara, J. P. and Valdez, F., 2005. Adipose tissue metabolism and production responses to calcium propionate and chromium propionate. J. Dairy Sci., 88: 498-507.

Melrose, D. and Laing, R., 1970. Fertility and infertility in the domestic Anim.s. $2^{\text {nd }}$ edition Bailer. Tindal and Cassel, London.

Mertz, W. 1993. Chromium in human nutrition: A review. J. Nutr. 123:626. National Academy Press, Washington. D.C.

Miazzo, R.; Peralta, M.F.; Magnoli, C.; Salvano, M.; $\quad$ Ferrero, S.; Chiacchiera, S.M.; Carvalho, E.C.Q.; Rosa, C.A.R. and Dalcero, A., 2005. Efficacy of sodium bentonite as a detoxifier of broiler feed contaminated with aflatoxin and fumonisin. Poult. Sci., 84: 1-8.

Moghadam, N. A; Sadeghi, A.; Ghahri, H. and Shawrang, P., 2008. Effects of yeast cell wall and sodium bentonite on antibody titers of broiler chickens fed ration containing aflatoxin. Proc of British Society of Anim. Sci. (BSAS), Scarborough, UK, 31 March-2 April, 2008, pp: 79-83

Monks, R. 1992. True feed sodium bentonite registered as a stock medicine. New release. Australian Bentonite, A division of Cudgen R.Z. Ltd. Brisbane, Australia.

Nasir, A.T.; Chughtai Z. I. and Farooqi, Z.A., 2000. Effect of different levels of himah bs-7 (sodium bentonite) on the performance of commercial layers. Pak Vet. J. , 20 : 105-106.

Nattapon, S.; Jin-Jenn, L.; Alex, T. and Tu-Fa Lien., 2012. Effect of different level of nanoparticles of $\mathrm{CrPic}$ supplementation on performance, egg quality, retention and tissue mineral accumulation in layers. J. Agr. Sci.; 5(2): 150-159.

Nowar, M.S.; Abd El-Rahim, M.I.; ElGaafary, M.N.; Tawfeek, M.I.; Ibrahim, Z.A. and Abdallh, F.R., 2000. Effectiveness of Egyptian raw bentonite in prevention or diminution the detrimental effects of aflatoxinsnaturally contaminated dietson reproductive performance, blood biochemistry and digestibility in rabbits. Proceedings $22^{\text {th }}$ Mycotoxin Workshop, as a special issue of the $\mathrm{J}$. of Mycotoxin Research, 16 A (2)P:199203.

Okada, S.; Suzuki, M. and Ohba, H. 1983. Enhancement of ribonucleic acid synthesis by chromium (III) in mouse liver. J. Inorg. Biochem. 19:95-103.

Ortatatli, M; Ciftci, M. K.; Tuzcu, M. and Kaya, A., 2002. The effects of aflatoxin on the reproductive system of roosters. Res Vet Sci, , 72, 29-36.

Pasha, T. N.; Mahmood, A.; Khattak, F.M.; Jabbar, M.A. and Khan, A.D., 2008. The effect of feed supplemented with different sodium bentonite treatments on broiler performance. Turk. J. Vet. Anim. Sci., 32: 245-248. 
Piva, A.; Meola, E.; Gatta, P. P.; Blagi, G. C.; Mordenti, A. L.; Luchansky, J. B.; Silva, S. and Mordenti, A., 2003. The effect of dietary supplementation with trivalent chromium on production performance of laying hens and the chromium content in the yolk. Anim. Feed Sci. Tech. 106: 149-163.

Poccia, D., 1994. Intercellular signaling systems. In: Poccia D (Editor), Molecular Aspects of Spermatogenesis. R.G. Landes Company, Austin, TX, USA.

Preuss, H. G.; Grojec, P. L.; Lieberman, S. and Anderson, R. A., 1997. Effects of different chromium compounds on blood pressure and lipid peroxidation in spontaneously hypertensive rats. Clin. Nephrol., 47: 325-330.

Rosebrough, R.W. and Steele, N.C., 1981. Effect of supplemental dietary chromium or nicotic acid on carbohydrate metabolism during basal, starvation and refeeding periods in poults. Poult. Sci.; 60:407-11.

Safaeikatouli M.; Boldaji, F.; Dastar, B. and Hassani, S.; 2010. Effect of different levels of kaolin, bentonite and zeolite on broilers performance. J. Biol. Sci., 10: 58-62.

Sahin, K. ; Ozbey, O.; Onderci, M.; Cikim, G. and Aysondu, M. H., 2002a. Chromium supplementation can alleviate negative effects of hot climate on egg production, egg quality and some serum metabolites of laying Japanese quail. J. Nutr., 132: 12651268.

Sahin, K.; Kucuk, O. and Sahin, N., 2001a. Effects of dietary chromium picolinate supplementation on performance, insulin and corticostrerone in laying hens under low ambient temperature. J. Anim. Physiol. Anim. Nutr., 85: 142-147.

Sahin, K.; Kucuk, O.; Sahin, N. and Ozbey, O., 2001b. Effects of dietary chromium picolinate supplementation on egg production, egg quality, and serum concentrations of insulin, corticostrerone and some metabolites of Japanese quails. Nutr. Res., 21: 13151321.

Sahin, N.; Onderci, M. and Sahin, K., 2002b. Effects of dietary chromium and zinc on egg production, egg quality and some blood metabolites of laying hens reared under low ambient temperature. Biol. Trace Elem. Res., 85: 47-58.

SAS Institute., 2004. SAS / DSTAT User s Guide. SAS Institute Inc., Cary,Nc.

Seaborn, C. D.; Cheng, N.; Adeleye, B.; Owens, F. and Stoecker, B. J., 1994. Chromium and chronic ascorbic acid depletion effects on tissue ascorbate, manganese, and $14 \mathrm{C}$ retention from 14C-ascorbate in guinea pigs. Biol. Trace Elem. Res., 41: 279-294.

Shrivastava, R.; Upreti, RK; Seth, PK; Chaturvedi, UC, 2002. Effects of chromium on the immune system. FEMS Immunol. and Med. Microbiol. 34: 1-7.

Tauqir, N.A. and Nawaz, H., 2001. Performance and economics of broiler chicks fed on rations supplemented with different levels of sodium Bentonite. Int. J. Agri. Biol., 3: 149-150.

Tauqir, N.A.; Chughtai, Z.I. and Farooqi, Z.A., 2000. Effect of different levels of Himax BS-7 (sodium bentonite) on the performance of commercial layers. Pak Vet J., 20, 105106.

Tawfeek, S. S. ; Abdella, K. M. and Youssef, I. M., 2014. The effect of dietary supplementation of some antioxidants on performance, oxidative stress and blood parameters in broilers under natural summer condition. J. World's Poult. Res., 4(1): 10-14.

Trckova, M., L. Matlova, L. Dvorska, and I. Pavlik (2004). Kaolin, bentonite, and zeolites as feed supplements for animals: health advantages and risks. Vet. Med. Czech, 49:389-399.

Trout, J. M.; Mashaly, M. M. and Siegel, H. S. 1996. Changes in blood and spleen 
lymphocyte populations following antigen challenge in immature male chickens. Br. Poult. Sci., 37: 819-827.

Uyanik, F.; Kaya, S.; Kolsuz, A. H.; Eren, M. and Sahin, N., 2002. The effect of chromium supplementation on egg production, egg quality and some serum parameters in laying hens. Turk. J. Vet. Anim. Sci., 26: 379-387.

Valenzuela, A., 1991. The biological significance of malondialdehyde determination in the assessment of tissue oxidative stress. Life Sci.s., 48: 301-309.
Vincent, J.B., 2000. The biochemistry of chromium. J. Nutr., 130:715-718.

Weydert, C.J. and Cullen, J.J., 2010. Measurement of superoxide dismutase, catalase and glutathione peroxidase in cultured cells and tissue. Nature Protocols., 5:51-66.

Yıldız, A. O.; Parlat, S. S. and Yazgan, O., 2004. The effects of organic chromium supplementation on production traits and some serum parameters of laying quails. Revue. Med. Vet., 155: 642-646.

$$
\begin{aligned}
& \text { تأثير إضافة بنتونيث الصوديوم والكروميوم العضوي في العليقة على الأداء الإنتاجي والفسيولوجي }
\end{aligned}
$$

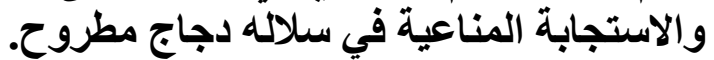

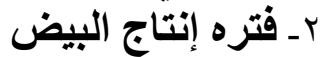

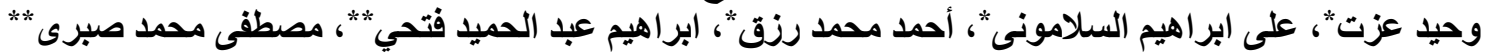

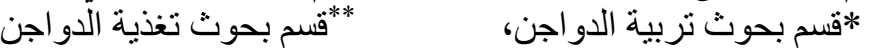

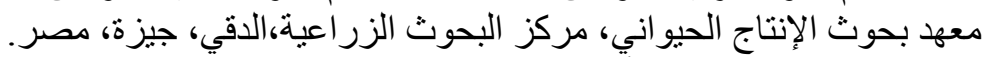

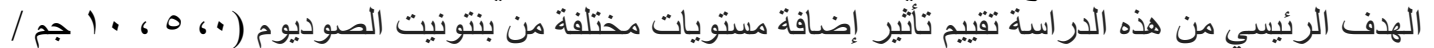

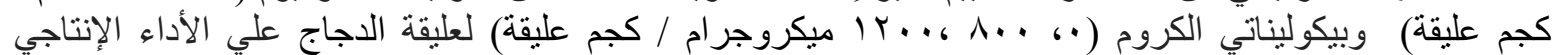

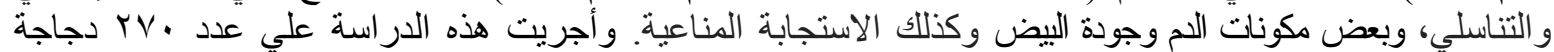

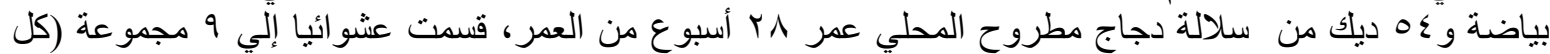

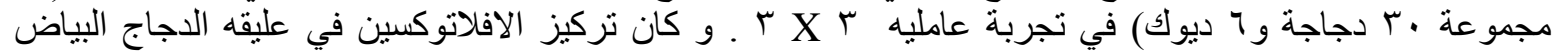

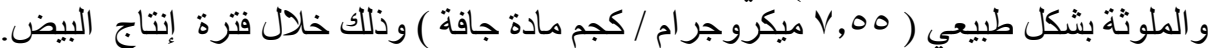

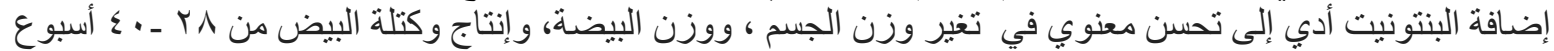

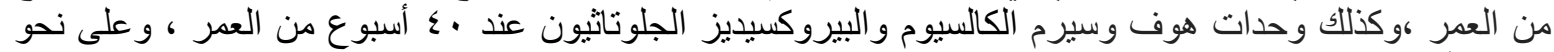

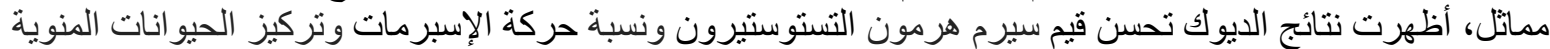

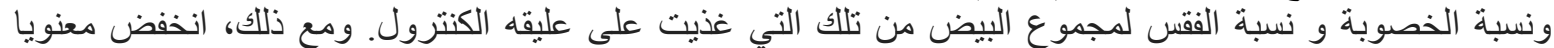

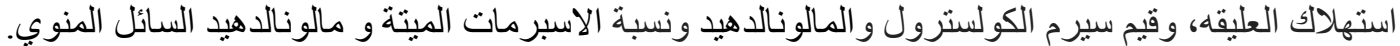

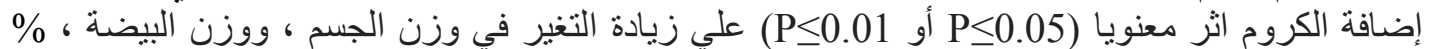

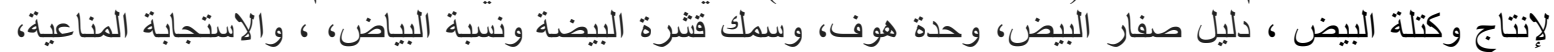

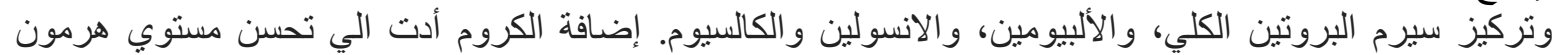

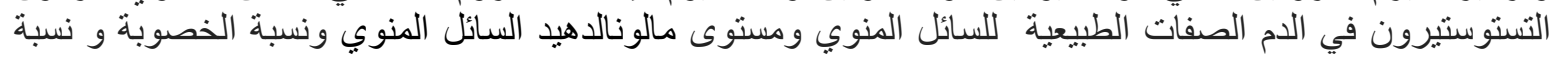

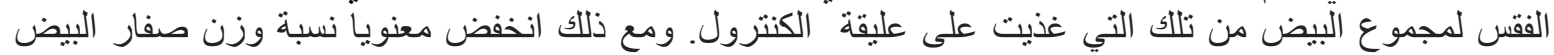

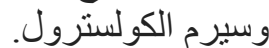

و علاوة على ذلك، ت تأثر معنويا تداخل التغذية بين بنتونيت الصوديوم وبيكوليناتي الكروم علي وزن البيضة

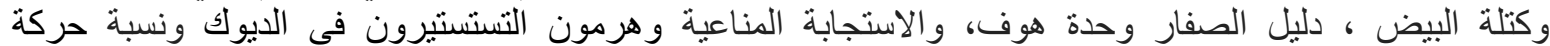

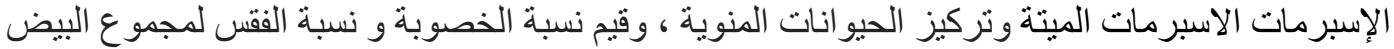

